\title{
BERPIKIR ALJABAR MAHASISWA DALAM MENYELESAIKAN MASALAH BERDASARKAN TAKSONOMI SOLO DITINJAU DARI KEMAMPUAN MATEMATIKA
}

\author{
Siti Napfiah \\ IKIP Budi Utomo Malang \\ napfiahsiti@gmail.com
}

\begin{abstract}
ABSTRAK
Penelitian ini ditujukan untuk mendeskripsikan profil berpikir aljabar mahasiswa dalam menyelesaikan masalah berdasarkan taksonomi SOLO ditinjau dari perbedaan kemampuan matematika. Penelitian ini termasuk penelitian kualitatif. Hasil penelitian menunjukkan bahwa berpikir aljabar mahasiswa berkemampuan matematika tinggi dalam menyelesaikan masalah berdasarkan taksonomi SOLO pada komponen pola mencapai level extended abstract dengan mengenali contoh pola bilangan kemudian membuat soal yang berkaitan dengan pola di luar pengetahuan yang diasumsikan dan menggeneralisasikan pola tersebut, pada komponen variabel mencapai level relational dengan cara membuat hubungan diantara hasil bilangan yang telah disubstitusikan ke dalam bentuk aljabar, pertidaksamaan dan persamaan yang diberikan. Selain itu, berpikir aljabar mahasiswa berkemampuan matematika sedang dalam menyelesaikan masalah berdasarkan taksonomi SOLO yaitu pada komponen pola mencapai level unistructural dalam menemukan suku tertentu dari pola yang diberikan dengan hanya menggunakan satu penggal informasi dari data yaitu hanya mengenal hubungan antara nilai suku dari pola yang diketahui tetapi tidak menggunakan hubungan untuk menemukan nilai suku yang lebih tinggi dan menggeneralisasikan pola yang diberikan, pada komponen variabel mencapai level multistructural dengan mensubstitusikan beberapa bilangan pada bentuk aljabar, persamaan, dan pertidaksamaan tetapi tidak dapat membuat hubungan diantara hasil substitusi tersebut. Sedangkan berpikir aljabar mahasiswa berkemampuan matematika rendah dalam menyelesaikan masalah berdasarkan taksonomi SOLO yaitu untuk komponen pola pada level prestructural karena menggunakan informasi yang tidak relevan dan untuk komponen variabel pada level unistructural dengan menggunakan hanya satu bilangan tertentu.
\end{abstract}

Kata Kunci : berpikir aljabar, taksonomi SOLO, kemampuan matematika.

\section{PENDAHULUAN}

Seorang dosen perlu memperhatikan perkembangan berpikir aljabar mahasiswanya. Berpikir aljabar penting untuk diperhatikan karena seperti yang diungkapkan Kamol, dkk (2003) bahwa aljabar memainkan peranan penting dalam kurikulum sekolah sehingga pendidik perlu memperhatikan berpikir aljabar peserta didiknya.

Seperti yang diungkapkan Cai, Jinfa dan John C. Moyer (2007) bahwa pengajar perlu mendukung perkembangan peserta didik dalam berpikir aljabar sejak awal sebagai cara untuk membantu mereka membuat transisi yang halus antara aritmetika dan aljabar, 
dan sebagai cara untuk membantu mereka mengerti kegunaan pendekatan secara umum untuk menyelesaikan berbagai masalah. Kriegler (2008) juga mengatakan bahwa berpikir aljabar siswa harus diperhatikan dengan baik oleh pengajar matematika di tingkat sekolah dasar dan menengah untuk mempersiapkan kemampuan siswa berpikir kritis yang diperlukan dalam berpartisipasi di masyarakat yang demokratis dan untuk kesuksesan pengalaman tentang aljabar. Berdasarkan hasil penelitian Kamol, dkk pada tahun 2003, Cai, Jinfa dan John C. Moyer pada tahun 2007, Linsell, et all pada tahun 2007, dan Kriegler pada tahun 2008 yang menemukan temuan yang sama yaitu pentingnya seorang pengajar memperhatikan berpikir aljabar peserta didiknya di semua tingkat sekolah.

Delyana (2015) menyatakan bahwa tingginya hasil belajar matematika siswa tidak diikuti dengan tingginya kemampuan pemecahan masalah sehingga mereka mengalami kesulitan ketika menghadapi permasalahan matematis. Selain itu, Abdul (2008) mengungkapkan bahwa guru perlu memeperhatikan pembelajaran dalam pemecahan masalah agar siswa memiliki kemampuan menyelesaikan masalah dengan baik. Berdasarkan hal-hal tersebut, maka seseorang dituntut untuk cakap menyelesaikan masalah. Maka pembelajaran matematika sebaiknya dirancang dengan menempatkan masalah sebagai topik utama dalam kegiatan pembelajaran yang akan membekali kemampuan mahasiswa untuk menyelesaikan masalah dalam kehidupan.

Kemampuan mahasiswa dalam menyelesaikan masalah dapat dilihat dari respons mereka ketika berhadapan dengan masalah matematika. Seorang dosen tidak dapat melihat langsung kemampuan mahasiswa dalam menyelesaikan masalah melalui proses berpikir yang sedang terjadi, tetapi dapat mengetahui kemampuan itu dari kualitas respons-respons yang diberikan. Untuk mengetahui respons mahasiswa, seorang dosen dapat menggunakan taksonomi SOLO (Structure of Observed Learning Outcomes). Sebagaimana yang diungkapkan Biggs \& Collis (dalam Hamdani, 2009) bahwa taksonomi SOLO dapat digunakan untuk mengetahui kualitas respons seseorang terhadap suatu tugas.

Taksonomi SOLO terdiri dari lima level, yaitu prestructural, unistructural, multistructural, relational, dan extended abstract. Setiap level tersebut yaitu: (1) level prestructural, respons yang diberikan tidak relevan; (2) level unistructural, respons yang diberikan menggunakan satu penggal informasi; (3) level multistructural, respons yang diberikan menggunakan beberapa penggal informasi tetapi tidak dapat memberikan hubungan diantara data-data yang diperoleh; (4) level relational, respons yang diberikan dengan memadukan penggalan-penggalan informasi yang terpisah untuk menghasilkan 
penyelesaian dari suatu masalah; (5) level extended abstract, respons yang diberikan hampir sama dengan respons pada level relational tetapi data atau konsep dan proses ditarik dari luar pengetahuan yang diasumsikan pada pertanyaan.

Berpikir aljabar memiliki keterkaitan dengan taksonomi SOLO karena taksonomi SOLO dapat digunakan sebagai alat untuk mengkategorikan berpikir aljabar seseorang. Seperti penelitian yang dihasilkan Kamol (2005) yaitu mengenai kerangka berpikir aljabar seseorang yang dikarakterisasikan berdasarkan taksonomi SOLO.

Melalui taksonomi SOLO dapat dilihat respons mahasiswa dalam berpikir aljabar untuk menyelesaikan suatu masalah. Tujuan penelitian ini adalah untuk mendeskripsikan profil berpikir aljabar mahasiswa dalam menyelesaikan masalah berdasarkan taksonomi SOLO ditinjau dari perbedaan kemampuan matematika.

Berpikir aljabar berhubungan dengan kemampuan matematika mahasiswa. Hal ini dikarenakan perbedaan kemampuan matematika mahasiswa dapat menghasilkan perbedaan dalam berpikir aljabar. Untuk melihat kebenaran ini, peneliti melakukan uji coba sederhana yakni dengan memberikan soal yang dapat memacu berpikir aljabar mahasiswa. Uji coba dilakukan sebelum dilakukan penelitian. Berdasarkan hasil uji coba, diketahui bahwa mahasiswa yang memiliki kemampuan matematika lebih tinggi dapat mengidentifikasi hubungan antara nilai suku dan urutannya dengan memberikan rumus untuk sebarang bilangan, sedangkan mahasiswa dengan kemampuan matematika lebih rendah hanya mengenali selisih antar nilai suku tanpa mengetahui hubungan antara nilai suku dan urutannya. Sehingga terdapat perbedaan berpikir aljabar diantara mahasiswa yang memiliki kemampuan matematika berbeda.

Kamol (2005:39) mengungkapkan bahwa untuk melihat berpikir aljabar dapat menggunakan komponen pola dan variabel. Berpikir aljabar pola mengacu pada kemampuan seseorang menggunakan keterampilan berpikirnya untuk menggeneralisasi pola dalam bentuk simbolik. Berpikir aljabar variabel mengacu pada kemampuan seseorang menggunakan keterampilan berpikirnya untuk memahami peran variabel sebagai bilangan yang diperumum. Kamol (2005:63) mengungkapkan bahwa berpikir aljabar seseorang pada pola merefleksikan kemampuan seseorang untuk menggeneralisasi pola dalam bentuk simbolik. Jadi pola merefleksikan kemampuan seseorang untuk : (a) menemukan suku tertentu dari pola yang diberikan; (b) menggeneralisasikan pola yang diberikan. Selain itu, Kamol (2005:123) mengatakan bahwa variabel melibatkan pemahaman pada peran variabel. Indikator ini mengenai kemampuan seseorang untuk 
memahami peran variabel sebagai bilangan yang diperumum pada bentuk aljabar, persamaan dan pertidaksamaan.

Berpikir aljabar dalam penelitian ini diartikan sebagai kegiatan mental yang menghasilkan pengetahuan mengenai hubungan antara kuantitas-kuantitas yang direpresentasikan dengan menggunakan simbol. Sedangkan komponen berpikir aljabar pada penelitian ini difokuskan pada komponen pola dan variabel. Indikator yang digunakan untuk melihat berpikir aljabar mahasiswa yaitu menemukan suku tertentu dari pola yang diberikan, menggeneralisasikan pola yang diberikan, dan memahami peran variabel sebagai bilangan yang diperumum pada bentuk aljabar, persamaan dan pertidaksamaan.

Berdasarkan paparan di atas, tujuan penelitian ini adalah untuk mendeskripsikan profil berpikir aljabar mahasiswa dalam menyelesaikan masalah berdasarkan taksonomi SOLO ditinjau dari kemampuan matematika. Kemampuan matematika mahasiswa dibedakan menjadi tiga macam yaitu kemampuan matematika tinggi, sedang, dan rendah.

\section{METODE PENELITIAN}

Penelitian ini dimaksudkan untuk mendeskripsikan profil berpikir aljabar mahasiswa berkemampuan tinggi dalam menyelesaikan masalah berdasarkan taksonomi SOLO. Berdasarkan hal tersebut, penelitian dikategorikan dalam jenis penelitian deskriptif dengan menggunakan pendekatan kualitatif.

Lokasi yang dipilih pada penelitian ini adalah salah satu perguruan tinggi di Malang. Kriteria pengelompokannya yaitu sesuai skor matematika (SM) sebagai berikut: (1) mahasiswa yang memiliki kemampuan matematika tinggi adalah mahasiswa yang memperoleh skor matematika antara 75 dan 100, (2) mahasiswa yang memiliki kemampuan matematika sedang adalah mahasiswa yang memperoleh skor matematika kuarang dari 75 dan lbih dari atau sama dengan 60, (3) mahasiswa yang memiliki kemampuan matematika rendah adalah mahasiswa yang memperoleh skor matematika kurang dari 60.

Pengumpulan data penelitian dimulai dengan pemberian soal masalah kepada subjek. Subjek diminta untuk menyelesaikan soal. Setelah tugas selesai dikerjakan, dilakukan wawancara. Hasil wawancara kemudian ditranskip dan digabung dengan hasil pekerjaan tertulis subjek.

Jika data yang diperoleh tidak valid, artinya terjadi ketidaksesuaian antara tugas tertulis pertama yang dikerjakan subjek dengan yang kedua, dan ketidakcocokan antara 
hasil wawancara yang pertama dan yang kedua, maka dilaksanakan tugas ketiga. Validasi data yang digunakan peneliti yaitu dengan pengecekan ulang dengan waktu yang berbeda yang disebut triangulasi waktu.

Tahapan analisis data dikutip dari Moleong (2007) yaitu meliputi (a) membaca/mempelajari data, menandai kata-kata kunci dan gagasan yang ada pada data, (b) mempelajari kata-kata kunci untuk menemukan tema-tema yang berasal dari data, (c) menuliskan model yang ditemukan, dan (d) koding yang telah dilakukan. Untuk pengkodean pemaparan data, dibuat pengkodean yang terdiri dari 6 digit dengan rincian keterangan sebagai berikut. (i) Tiga digit pertama berupa huruf JST, JSS, atau JSR. Huruf JST menyatakan jawaban subjek berkemampuan matematika tinggi, huruf JSS menyatakan jawaban subjek berkemampuan matematika sedang, dan huruf JSR menyatakan jawaban subjek berkemampuan matematika rendah. (ii) Digit keempat berupa angka yang menyatakan wawancara berbasis tugas (tugas ke-1, 2, atau 3). (iii) Digit kelima berupa huruf $\mathrm{P}$ atau V. Huruf $\mathrm{P}$ menyatakan soal yang berkaitan dengan pola dan huruf V menyatakan soal yang berkaitan dengan variabel. (iv) Digit keenam berupa huruf a, b, c, atau $d$. Huruf a menyatakan jawaban poin a, huruf $b$ menyatakan jawaban poin $b$, huruf $c$ menyatakan jawaban poin $\mathrm{c}$, dan huruf $\mathrm{d}$ menyatakan jawaban poin $\mathrm{d}$.

Pada penelitian ini, data diperoleh dari wawancara mendalam terhadap subjek penelitian. Setelah dilakukan wawancara, membuat transkrip hasil wawancara dengan cara memutar rekaman wawancara kemudian menuliskan kata-kata yang didengar sesuai rekaman. Selanjutnya dilakukan proses mereduksi data yaitu membuang data yang tidak relevan, membuat ringkasan yang terorganisir, dan menggolongkan dalam satu pola yang lebih luas. Dalam proses ini, analisis tentang berpikir aljabar mahasiswa sudah dapat dilakukan. Selanjutnya dilakukan penyajian data yang dibuat dengan tersusun rapi dan terorganisir. Setelah itu dilakukan penarikan kesimpulan yang didasarkan pada hasil analisis terhadap data yang telah terkumpul dengan membandingkan kesesuaian pernyataan subjek dengan makna yang terkandung dalam pertanyaan penelitian yang diteliti untuk mendeskripsikan berpikir aljabar mahasiswa dalam menyelesaikan masalah berdasarkan taksonomi SOLO.

Secara garis besar, langkah-langkah dalam penelitian ini meliputi kegiatan sebagai berikut: (1) kegiatan awal yakni dengan mengkaji teori berpikir aljabar untuk selanjutnya membuat laporan dan menyusun draf instrumen, (2) kegiatan inti yang dilakukan dengan pemberian tes kemampuan matematika untuk memilih subjek yang diinginkan untuk 
selanjutnya diberikan tugas menyelesaikan masalah dan wawancara, serta (3) kegiatan akhir yang meliputi pengolahan dan analisis data sehingga dapat merumuskan berpikir aljabar mahasiswa dalam menyelesaikan masalah untuk menyusun laporan penelitian dan penyimpulan akhir.

\section{HASIL DAN PEMBAHASAN}

Berikut disajikan beberapa hasil jawaban subjek penelitian. Gambar 1 memperlihatkan jawaban subjek kemampuan matematika tinggi pada tugas kesatu pada komponen variabel poin a.

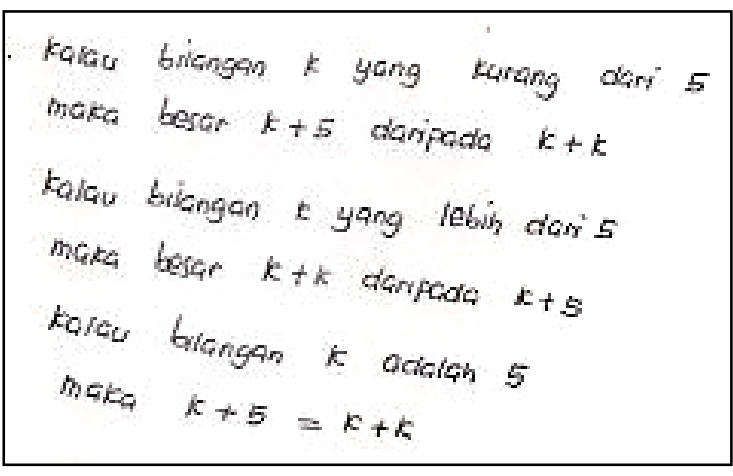

Gambar 1. JST1Va

Jawaban subjek kemampuan matematika sedang pada tugas kesatu pada komponen variabel poin a terlihat pada gambar 2 .

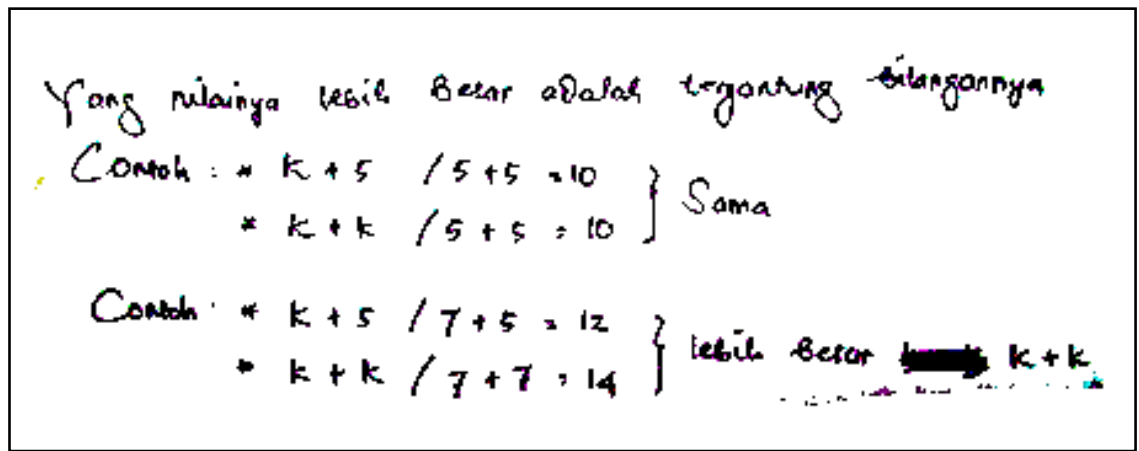

Gambar 2. JSS1Va

Jawaban subjek kemampuan matematika rendah pada tugas kesatu pada komponen variabel poin a terlihat pada gambar 3 .

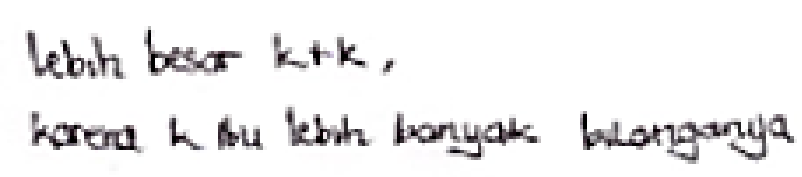

Gambar 3. JSR1Va 


\section{Berdasarkan penelitian yang telah dilakukan,diperoleh hasil sebagaimana} dijabarkan pada tabel 1, 2, dan 3 .

Tabel 1. Hasil penelitian terhadap subjek kemampuan matematika tinggi

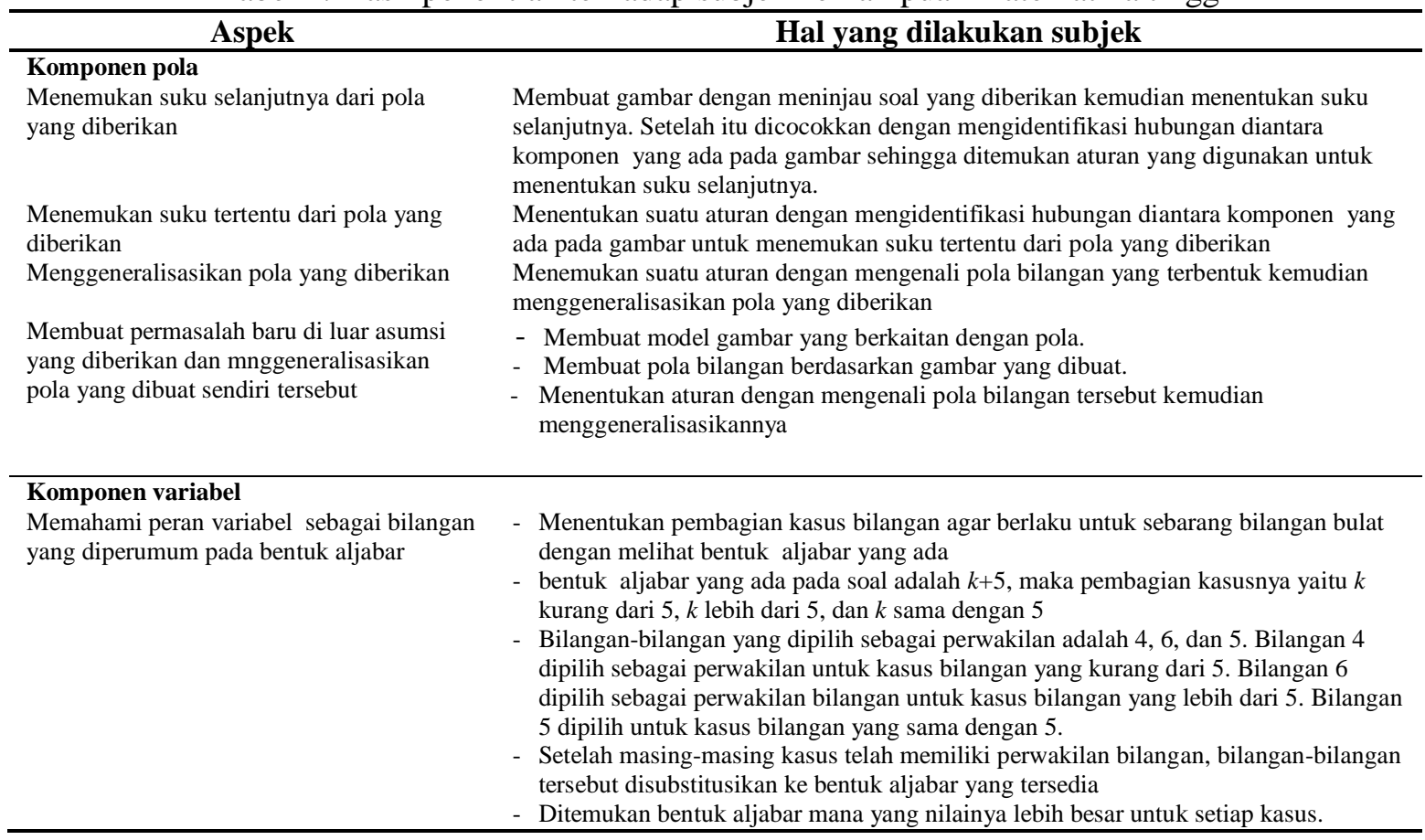

Tabel 2. Hasil penelitian terhadap subjek kemampuan matematika sedang

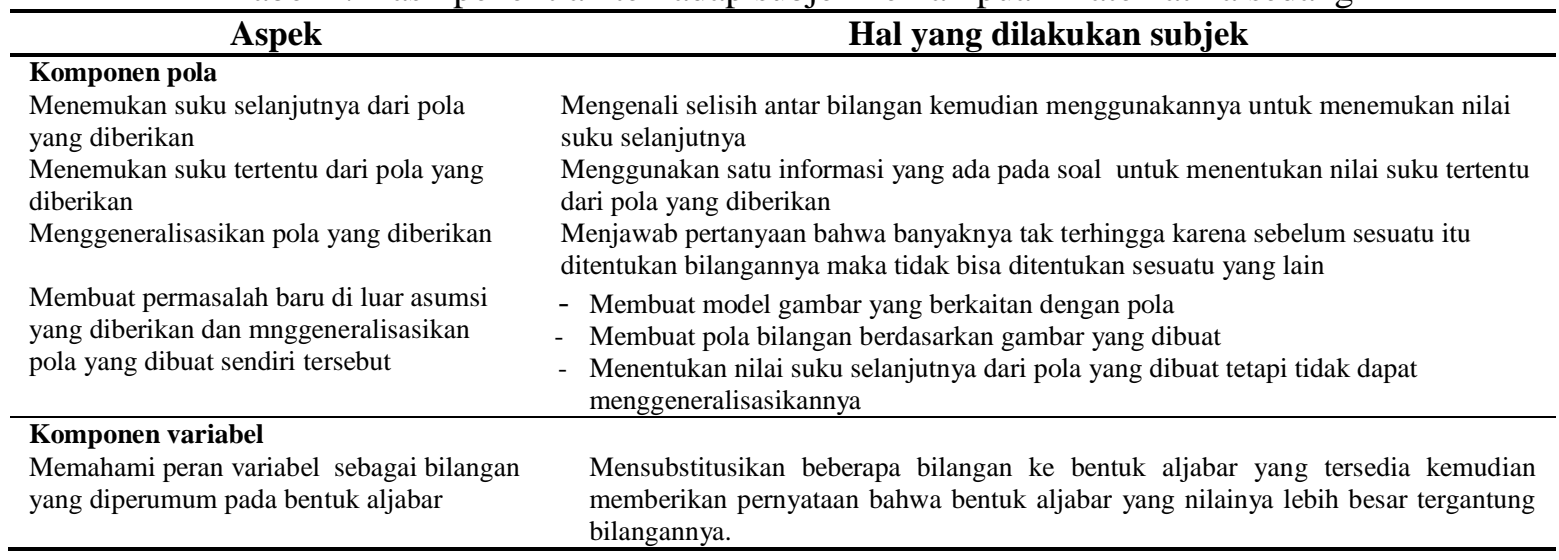

Tabel 3. Hasil penelitian terhadap subjek kemampuan matematika rendah

\begin{tabular}{|c|c|}
\hline Aspek & Hal yang dilakukan subjek \\
\hline \multicolumn{2}{|l|}{ Komponen pola } \\
\hline $\begin{array}{l}\text { Menemukan suku selanjutnya dari pola } \\
\text { yang diberikan }\end{array}$ & Menggunakan satu informasi dari soal dalam menentukan nilai suku selanjutnya \\
\hline $\begin{array}{l}\text { Menemukan suku tertentu dari pola yang } \\
\text { diberikan }\end{array}$ & $\begin{array}{l}\text { Menggunakan satu informasi dari soal dalam menentukan nilai suku tertentu dari pola } \\
\text { yang diberikan }\end{array}$ \\
\hline Menggeneralisasikan pola yang diberikan & Memberikan jawaban bahwa banyaknya adalah $x$ ditambah bilangan yang paling awal \\
\hline Membuat permasalah baru di luar asumsi & - Membuat model gambar yang berkaitan dengan pola \\
\hline $\begin{array}{l}\text { yang diberikan dan mnggeneralisasikan } \\
\text { pola yang dibuat sendiri tersebut }\end{array}$ & $\begin{array}{l}\text { - Menentukan nilai suku selanjutnya dari pola yang dibuat tetapi tidak dapat } \\
\text { menggeneralisasikannya }\end{array}$ \\
\hline \multicolumn{2}{|l|}{ Komponen variabel } \\
\hline $\begin{array}{l}\text { Memahami peran variabel sebagai bilangan } \\
\text { yang diperumum pada bentuk aljabar }\end{array}$ & $\begin{array}{l}\text { Memberikan jawaban bahwa } k+k \text { lebih besar daripada } k+5 \text { karena jika ditambahkan } \\
k+k \text { hasilnya lebih banyak }\end{array}$ \\
\hline
\end{tabular}


Berdasarkan hasil analisis terhadap data penelitian, diketahui berbagai macam cara yang dilakukan mahasiswa dalam menyelesaikan masalah. Berikut akan dipaparkan berpikir aljabar mahasiswa dalam menyelesaikan masalah berdasarkan taksonomi SOLO ditinjau dari perbedaan kemampuan matematika.

Berpikir aljabar mahasiswa kemampuan matematika tinggi dalam menyelesaikan masalah pada komponen pola yaitu menemukan suku tertentu dari suatu pola bilangan dengan cara mengidentifikasi susunan model gambar kemudian mentransformasikannya ke dalam konsep matematika, menggeneralisasikan pola yang diberikan dengan cara mengenali pola bilangan kemudian mentransformasikannya ke dalam konsep matematika, serta membuat soal yang berkaitan dengan pola tetapi pola yang dibuat berbeda dengan pola yang ada pada soal kemudian membuat generalisasi pola tersebut. Dengan demikian mahasiswa dapat membuat soal yang berkaitan dengan pola di luar pengetahuan yang diasumsikan dan kemudian menggeneralisasikan pola tersebut. Berdasarkan penjelasan tersebut, respons yang diberikan mahasiswa cenderung ke level relational dan extended abstract berdasarkan taksonomi SOLO. Hal ini sesuai dengan pendapat Kamol (2005:54) bahwa pada level relational, seseorang memberikan rumus yang menentukan nilai sebarang suku. Selanjutnya, Chick (1998:6) mengungkapkan bahwa apabila respons yang diberikan hampir sama dengan relational tetapi data ditarik dari luar pengetahuan yang diasumsikan pada pertanyaan maka respons yang diberikan termasuk level extended abstract. Sedangkan berpikir aljabar mahasiswa dalam menyelesaikan masalah pada komponen variabel yaitu memahami peran variabel sebagai bilangan yang diperumum pada bentuk aljabar dengan menentukan suatu bilangan yang dapat dijadikan perwakilan dan memahami peran variabel sebagai bilangan yang diperumum pada persamaan dan pertidaksamaan dengan menentukan bilangan yang berlaku pada pertidaksamaan yang diberikan kemudian mensubstitusikannya ke dalam suatu persamaan yang ada sehingga menghasilkan kesimpulan dengan alasan yang logis. Dengan demikian dikatakan mahasiswa dapat memberikan hubungan diantara beberapa informasi yang diberikan sehingga respons yang diberikan cenderung ke level relational berdasarkan taksonomi SOLO. Hal ini didukung oleh pendapat Kamol (2005:57) bahwa pada level relational, seseorang memahami peran variabel sebagai bilangan yang diperumum dan memberikan kesimpulan dengan alasan yang logis.

Berpikir aljabar mahasiswa dalam menyelesaikan masalah berdasarkan taksonomi SOLO untuk mahasiswa kemampuan matematika sedang adalah pada komponen pola yaitu 
menemukan suku tertentu dari pola yang diberikan dengan hanya menggunakan satu penggal informasi dari data sehingga hanya dapat menemukan suku selanjutnya dari pola yang diketahui tetapi ketika mencari nilai suku yang lebih tinggi responsnya tidak relevan. Maka respons yang diberikan ini mencapai level unistructural berdasarkan taksonomi SOLO. Hal ini sesuai dengan pendapat Kamol (2005:53) bahwa pada level unistructural, seseorang hanya mengenal hubungan antara nilai suku dari pola yang diketahui tetapi tidak menggunakan hubungan untuk menemukan suku yang lebih tinggi. Sedangkan dalam menggeneralisasikan pola yang diberikan, mahasiswa mencapai level prestructural berdasarkan taksonomi SOLO karena memberikan jawaban yang tidak relevan. Sedangkan pada komponen variabel yaitu mahasiswa menggunakan beberapa bilangan tertentu tetapi tidak dapat membuat kesimpulan dengan tepat karena tidak mengetahui hubungan diantara informasi-informasi yang ada maka dikatakan mahasiswa kemampuan sedang mencapai level multistructural berdasarkan taksonomi SOLO. Hal ini seperti yang diungkapkan Kamol (2005:56) bahwa seseorang pada level multistructural tidak memahami secara penuh peran variabel sebagai bilangan yang diperumum.

Selain itu, berpikir aljabar mahasiswa dalam menyelesaikan masalah berdasarkan taksonomi SOLO untuk mahasiswa kemampuan matematika rendah yaitu pada komponen pola mahasiswa tidak dapat menemukan suku tertentu dan menggeneralisasikan pola yang diberikan karena menggunakan informasi yang tidak relevan, maka dalam hal ini mahasiswa hanya sampai pada level prestructural berdasarkan taksonomi SOLO. Sedangkan pada komponen variabel yaitu mahasiswa tidak memahami peran variabel sebagai bilangan yang diperumum pada bentuk aljabar, persamaan dan pertidaksamaan karena hanya menggunakan satu bilangan tertentu untuk menyelesaikan masalah yang dihadapi sehingga dikatakan respons yang diberikan mencapai level unistructural berdasarkan taksonomi SOLO. Hal ini didukung oleh pendapat Kamol (2005:56) bahwa seseorang pada level unistructural menggunakan hanya satu bilangan tertentu untuk membuat kesimpulan.

Berdasarkan hasil analisis yang telah dipaparkan, diketahui bahwa terdapat beberapa perbedaan penyelesaian masalah yang dilakukan mahasiswa kemampuan matematika tinggi, sedang, dan rendah dalam menyelesaikan masalah. Mahasiswa kemampuan matematika tinggi dapat memenuhi semua indikator berpikir aljabar dengan level respons untuk komponen pola sampai pada level extended abstract dan level respons untuk komponen variabel sampai pada level relational. Sedangkan mahasiswa kemampuan 
matematika sedang dan rendah tidak dapat memenuhi semua indikator berpikir aljabar, baik untuk komponan pola maupun variabel. Tetapi ada perbedaan diantara keduanya yakni pada komponen pola untuk indikator menemukan suku tertentu dari pola yang diberikan dan pada komponen variabel, mahasiswa kemampuan matematika sedang mencapai level respons unistructural, sedangkan siswa kemampuan matematika rendah mencapai level respons prestructural. Perbedaan yang menonjol lainnya yaitu pada komponen pola dengan indikator menggeneralisasikan pola yang diberikan. Pada mahasiswa kemampuan matematika tinggi dapat menggeneralisasikan pola dengan level respons relational, sedangkan mahasiswa kemampuan matematika sedang dan rendah tidak dapat menggeneralisasikan pola dengan level respons pestructural. Selain itu terdapat persamaan yang dimiliki ketiga subjek adalah ketika membaca soal untuk memahami masalah pada komponen variabel. Ketiga subjek memahami masalah pada komponen variabel dengan cara membaca soal berulang-ulang.

\section{KESIMPULAN}

Berdasarkan hasil analisis data penelitian dan pembahasan yang telah diuraikan, dapat ditarik kesimpulan bahwa profil berpikir aljabar mahasiswa dalam menyelesaikan masalah berdasarkan taksonomi SOLO ditinjau dari perbedaan kemampuan matematika adalah sebagi berikut.

1. Berpikir aljabar mahasiswa berkemampuan matematika tinggi dalam menyelesaikan masalah berdasarkan taksonomi SOLO adalah pada komponen pola cenderung pada level relational dan level extended abstract dengan menggeneralisasikan pola yang dibuat di luar pengetahuan yang diasumsikan dengan cara mengenali pola bilangan kemudian mentransformasikannya ke dalam konsep matematika. Sedangkan pada komponen variabel mencapai level relational dengan cara membuat hubungan diantara hasil bilangan yang telah disubstitusikan ke dalam bentuk aljabar, pertidaksamaan dan persamaan yang diberikan.

2. Profil berpikir aljabar dalam menyelesaikan masalah berdasarkan taksonomi SOLO pada mahasiswa kemampuan matematika sedang adalah pada komponen pola mencapai level unistructural dalam menemukan suku tertentu dari pola yang diberikan dengan hanya menggunakan satu penggal informasi dari data yaitu hanya mengenal hubungan antara nilai suku dari pola yang diketahui tetapi tidak menggunakan hubungan untuk menemukan nilai suku yang lebih tinggi dan mencapai level 
prestructural dalam menggeneralisasikan pola yang diberikan karena memberikan jawaban yang tidak relevan. Sedangkan pada komponen variabel mencapai level multistructural dengan cara mensubstitusikan beberapa bilangan ke dalam bentuk aljabar, pertidaksamaan dan persamaan yang diberikan, tetapi tidak dapat membuat hubungan diantara hasil substitusi yang telah dilakukan.

3. Profil berpikir aljabar dalam menyelesaikan masalah berdasarkan taksonomi SOLO pada mahasiswa kemampuan matematika rendah adalah pada komponen pola mencapai level prestructural karena menggunakan informasi yang tidak relevan. Sedangkan pada komponen variabel mencapai level unistructural dengan menggunakan hanya satu bilangan tertentu.

\section{REKOMENDASI}

Berdasarkan kesimpulan hasil penelitian di atas, saran yang dapat dikemukakan adalah sebagai berikut.

1. Mahasiswa dengan kemampuan matematika tinggi disarankan untuk dengan kemampuan matematika tinggi disarankan untuk diberikan soal mengenai pola dan variabel dengan tingkat kesulitan yang lebih tinggi agar berpikir aljabar siswa lebih baik lagi.

2. Mahasiswa dengan kemampuan matematika sedang disarankan agar sering diberikann latihan soal tentang menggeneralisasikan pola saat pembelajaran materi pola dan diberikan penguatan mengenai pengertian variabel ketika pembelajaran mengenai materi variabel.

3. Mahasiswa dengan kemampuan matematika rendah dapat diberikan bimbingan dalam menemukan suku tertentu dan menggeneralisasikan pola, serta perlu diberikan bimbingan juga mengenai pengertian variabel.

\section{REFERENSI}

Abdul, D. (2008). Strategi Pembelajaran Pemecahan Masalah di Sekolah Dasar. Diperoleh dari http://file.upi.edu/Direktori/JURNAL/PENDIDIKAN_DASAR/Nomor_10Oktober_2008/Strategi_Pembelajaran_Pemecahan_Masalah_di_Sekolah_Dasar.pdf (2016, 17 Januari).

Cai, J. \& Moyer, J. C. (2007). Developing Algebraic Thinking in Earlier Grades: Some Insights from International Comparative Studies. Diperoleh dari http://www.math.udel.edu/LIECAL/papers/YearbookCaiMoyer29_final_.pdf (2015, 7 Desember). 
Chick, H. (1998). Cognition in the Formal Modes: Research Mathematics and the SOLO Taxonomy. Mathematics Education Research Journal, 10(2), hal. 4-26.

Delyana, H. (2015). Peningkatan Kemampuan Pemecahan Masalah Matematika Siswa Kelas VII melalui Penerapan Pendekatan Open Ended. Jurnal LEMMA. 2(1), November.

Calvin, G. J. \& Maccini, P. (2001). Preparing Students with Disabilities for Algebra. Teaching Exceptional Children, 34(1), hal. 8-15.

Hamdani, A.S. (2009). Pengembangan Sistem Evaluasi Pembelajaran Pendidikan Agama Islam Berbasis Taksonomi SOLO. 1(1), Juni.

Kamol, dkk. (2003). A Framework in Characterizing

Lower Secondary School Students' Algebraic Thinking. Diperoleh dari https://pipl.com/directory/name/Kamol/180/ (2015, 2 Desember).

Kamol, N. (2005). A Framework in Characterizing Lower Secondary School Students' Algebraic Thinking. Doctoral Dissertation, Srinakharinwirot University.

Kamol, N. \& Har, Y. B.. (2015). Upper Primary School Students' Algebraic Thinking. In L. Sparrow, B. Kissane, and C. Hurst (Eds.), Shaping the future of mathematics education: Proceedings of the $33 \mathrm{rd}$ annual conference of the Mathematics Education Research Group of Australasia. Fremantle, Australia: MERGA.

Kriegler, S. (2008). Just What Is Algebraic Thinking. Diperoleh dari http://www.mathandteaching.org/uploads/Articles_PDF/articles-01-kriegler.pdf (2015, 5 Desember).

Linsell, et al. (2007). Early Algebraic Thinking: Links to Numeracy. Paper dipublikasikan di website TLRI (www.tlri.org.nz).

Moleong, L. J. (2007). Metodologi Penelitian Kualitatif. Bandung: Rosdakarya 